Check for updates

Cite this: J. Mater. Chem. A, 2021, 9, 505

Received 24th September 2020 Accepted 18th November 2020

DOI: $10.1039 / \mathrm{d} 0 \mathrm{ta} 09404 \mathrm{~h}$

rsc.li/materials-a

\section{High-performance all-organic aqueous batteries based on a poly(imide) anode and poly(catechol) cathode $\uparrow$}

\author{
Nagaraj Patil, (DD *a Andreas Mavrandonakis, (iD) a Christine Jérôme, (iD ${ }^{\mathrm{b}}$ \\ Christophe Detrembleur, (iD ${ }^{\mathrm{b}}$ Nerea Casado, (D) ${ }^{\mathrm{c}}$ David Mecerreyes, (D) cd \\ Jesus Palma ${ }^{(D a}$ and Rebeca Marcilla (D) *a
}

\begin{abstract}
Aqueous all-polymer batteries (AqPBs) are foreseen as promising solutions for safe, sustainable, and highperformance energy storage applications. Nevertheless, their development is still challenging as it demands precise optimization of both electrodes and the electrolyte composition to be able to sustain a stable redox activity, while delivering an optimal voltage output. Herein, we report AqPBs based on a poly(imide) (PI) anode and poly(catechol) (PC) cathode that exhibit tunable cell voltage depending on the salt used in the aqueous electrolyte, i.e., $0.58,0.74,0.89$, and $0.95 \mathrm{~V}$, respectively, when $\mathrm{Li}^{+}, \mathrm{Zn}^{2+}, \mathrm{Al}^{3+}$, and $\mathrm{Li}^{+} / \mathrm{H}^{+}$ were utilized as charge carriers. The PI-PC full-cell delivers the best rate performance (a sub-second charge/discharge) and cycling stability (80\% capacity retention over 1000 cycles at $5 \mathrm{~A} \mathrm{~g}^{-1}$ ) in $\mathrm{Li}^{+}$. Furthermore, a maximum energy/power density of $80.6 \mathrm{~W} \mathrm{~h} \mathrm{kganode+cathode}{ }^{-1} / 348 \mathrm{~kW} \mathrm{~kg}_{\text {anode+cathode }}{ }^{-1}$ is achieved in $\mathrm{Li}^{+} / \mathrm{H}^{+}$, superior to most of the previously reported AqPBs.
\end{abstract}

\section{Introduction}

The proper integration of affordable, scalable and eco-friendly electrochemical energy storage (EES) systems is critical to facilitate the development of a safe, secure, and sustainable energy landscape. ${ }^{1,2}$ However, commercial Li-ion batteries exclusively include insertion-type inorganic anodes, 3d transition metal cathodes and organic electrolytes, which are unsafe, scarce, expensive and energy intensive, and hardly meet the requirements of a sustainable society. ${ }^{3}$ This calls for a radical change in research and development beyond Li-ion battery chemistries to meet the ever-increasing sustainability demands. ${ }^{4}$

Aqueous all-polymer batteries (AqPBs) that incorporate redox-active polymers (RAPs) as organic electrode materials (OEMs) and aqueous solutions as safe and cost-effective electrolytes can be promising alternatives for the development of sustainable energy storage systems. ${ }^{5-7}$ Although a plethora of RAPs have been successfully applied as OEMs in numerous

${ }^{a}$ Electrochemical Processes Unit, IMDEA Energy, Avda. Ramón de la Sagra 3, 28935 Móstoles, Madrid, Spain.E-mail: rebeca.marcilla@imdea.org; nagaraj.patil@imdea. org

${ }^{b}$ Centre for Education and Research on Macromolecules (CERM), CESAM Research Unit, Department of Chemistry, University of Liege, Allée de la Chimie B6A, 4000 Liége, Belgium

${ }^{\circ} P O L Y M A T$, University of the Basque Country UPV/EHU, Joxe Mari Korta Center, Avda. Tolosa 72, 20018 Donostia-San Sebastián, Spain

${ }^{d}$ Ikerbasque, Basque Foundation for Science, E-48011, Bilbao, Spain

$\dagger$ Electronic supplementary information (ESI) available: ESI Table, computational procedure and figures. See DOI: 10.1039/d0ta09404h rechargeable battery technologies (mostly, in metal-ion-polymer configuration), ${ }^{8-17}$ examples of AqPBs sporadically appeared in the literature..$^{\mathbf{1 8 , 1 9}}$ This is partly due to the formidable challenge that requires careful designing of both anode and cathode RAP partners to be not only able to sustain their redox activity in aqueous media, but also deliver a high voltage output within a relatively narrow electrochemical window of aqueous electrolytes $(\sim 1.23$ and $\sim 2 \mathrm{~V}$ for pure water and typical salt-in-water electrolytes, respectively). ${ }^{20-23}$

Based on the charge storage mechanisms of RAPs, they can be generally classified into: $n$-type undergoing $\mathrm{N} \leftrightarrow \mathrm{N}^{-}$, p-type undergoing $\mathrm{P} \leftrightarrow \mathrm{P}^{+}$, and bipolar exhibiting $\mathrm{B}^{-} \leftrightarrow \mathrm{B} \leftrightarrow \mathrm{B}^{+}$redox reactions, with the simultaneous shuttling of electroneutralizing cations, anions, and dual ions, respectively. ${ }^{8-15,18,19}$ Depending on the RAP (n- or p-type) and the chemical nature of the charge carriers, three kinds of AqPBs were realized: (i) n|ntype combination is generally preferred for the capacityoriented design (20-65 mA h g cell $\left.^{-1},<1 \mathrm{~V}\right),{ }^{24-26} \mathrm{p} \mid \mathrm{p}$-type combination mostly preferred for the voltage-oriented design (1.1$\left.1.3 \mathrm{~V},<45 \mathrm{~mA} \mathrm{~h} \mathrm{~g}_{\text {cell }}{ }^{-1}\right),{ }^{27-29}$ and $\mathrm{n} \mid \mathrm{p}$-type combination offers a compromise between the capacity and the voltage (10-52 $\mathrm{mA} \mathrm{h}$ $\mathrm{g}_{\text {cell }}{ }^{-1}$ and $\left.0.9-1.3 \mathrm{~V}\right)^{29-33}$ (Fig. S1 and Table S1, see the ESI $\dagger$ ). From these limited examples, it is evident that the development of AqPBs is at a slow pace and further it is necessary to simultaneously improve their capacity and voltage in order to be competitive with other aqueous-based battery technologies. ${ }^{\mathbf{1 8 , 1 9}}$

Among different varieties of n-type Redox-Active Polymers (RAPs), poly(imide)s and poly(quinone)s have been attracting tremendous interest in AqPBs owing to their (i) high theoretical 
specific capacity, tunable redox potentials and fast kinetics, (ii) high chemical and electrochemical stability, and (iii) good compatibility with different types of cationic charge carriers (e.g., $\mathrm{Li}^{+}, \mathrm{Na}^{+}, \mathrm{Mg}^{2+}, \mathrm{Zn}^{2+}, \mathrm{Al}^{3+}$, etc.) (vide supra). Particularly, their last merit is highly encouraging, which enables them to be used as universal organic electrodes in numerous polymerbased battery configurations. ${ }^{34-40}$ So far, their n-type redox behavior was mainly exploited to design various metal-ionpolymer mono- and multivalent batteries, but interactions between the polymeric host and the charge carriers were largely overlooked. Of note, our recent work emphasized the importance such interactions from the perspective of electrochemical performance tunability, but in half-cells. ${ }^{41}$

In this article, we demonstrate the construction of AqPBs, comprising a poly(imide) anode and poly(catechol) cathode. First, we studied the electrochemical performance of individual electrodes in different aqueous electrolytes containing $\mathrm{Li}^{+}, \mathrm{Zn}^{2+}$, $\mathrm{Al}^{3+}$, and $\mathrm{Li}^{+} / \mathrm{H}^{+}$charge carriers. Then, all-organic full-cells were tested denoting an increase of cell voltage depending on the charge carriers from $\mathrm{Li}^{+}$to $\mathrm{Zn}^{2+}$, to $\mathrm{Al}^{3+}$ and to $\mathrm{Li}^{+} / \mathrm{H}^{+}$, respectively. Finally, the performance of full-cells was optimized including cyclability studies and compared favorably with the state-of-the-art all-polymer aqueous stationary batteries.

\section{Experimental section}

\section{Materials}

Lithium nitrate $\left(\mathrm{LiNO}_{3}, \geq 99.0 \%\right.$, Sigma-Aldrich), zinc sulfate heptahydrate $\left(\mathrm{ZnSO}_{4} \cdot 7 \mathrm{H}_{2} \mathrm{O}, \geq 99.5 \%\right.$, Sigma-Aldrich), aluminum nitrate nonahydrate $\left(\mathrm{Al}\left(\mathrm{NO}_{3}\right)_{3}, 9 \mathrm{H}_{2} \mathrm{O}, \geq 98.0 \%\right.$, Sigma-Aldrich), sulfuric acid ( $\mathrm{H}_{2} \mathrm{SO}_{4}$, ACS reagent, 95-98\%, Sigma-Aldrich), anhydrous 1-methyl-2-pyrrolidone (NMP, $\geq 99.5 \%$, Sigma-Aldrich), lithium(I) bis(trifluoromethanesulfonyl)imide (LiTFSI; 99.9\%, Solvionic), zinc(II) bis(trifluoromethanesulfonyl)imide (Zn(TFSI) 99.5\%, Solvionic), aluminum(III) tris(trifluoromethanesulfonyl) imide ( $\mathrm{Al}(\mathrm{TFSI})_{3} ; 99.5 \%$, Solvionic), polyvinylidene fluoride (PVDF; Sigma Aldrich), thin multi-walled carbon nanotubes (CNTs; Elicarb® MW, Thomas-Swan) and carbon paper (Toray TP-060, QUINTECH) were used as received. Anhydrous $N, N$-dimethylformamide (DMF, $\geq 99.8 \%$, Sigma-Aldrich) was dried over $4 \AA$ molecular sieves for at least $48 \mathrm{~h}$, distilled, and stored under argon prior to use.

\section{Synthesis of redox-active polymers}

The synthesis of the cathode active-material, $\mathrm{P}\left(\mathrm{DA}_{70}\right.$-statAMPS $_{30}$ ) (termed simply poly(catechol) $=\mathrm{PC}, M_{\mathrm{n}} \approx 12.0 \mathrm{~kg}$ $\mathrm{mol}^{-1}$ and $M_{\mathrm{w}} / M_{\mathrm{n}} \approx 1.19$ ) bearing catechol pendants has been previously reported. ${ }^{42}$ The anode organic partner, poly $(1,4,5,8$ naphthalenetetracarboxylic diimide-1,2-diethoxyethane) (poly(imide) = PI) with imide functionalities in the polymer backbone, was synthesized by a polycondensation reaction as described previously. ${ }^{43}$

\section{Electrode preparation}

Preparation of the PC/CNT cathode. $5 \mathrm{mg}$ of thin multiwalled carbon nanotubes (CNTs) were dispersed in $3 \mathrm{~mL} \mathrm{1-}$ methyl-2-pyrrolidone (NMP) using a tip sonicator, followed by addition of $7.5 \mathrm{mg}$ of PC (the mass ratio of PC: CNT was $6: 4 \mathrm{wt} \%$ ), proceeding to sonication for $2 \mathrm{~h}$ in a bath sonicator (Branson 2510, $100 \mathrm{~W}, 42 \mathrm{kHz}$ ) and overnight stirring to prepare the electrode slurry. This viscous smooth slurry was then uniformly coated onto a carbon paper current collector by a doctor blade method, dried overnight at $50{ }^{\circ} \mathrm{C}$ under vacuum and cut into $12-\mathrm{mm}$ disks. The mass loading of polymers on the current collector was controlled between 1.1 and $1.5 \mathrm{mg} \mathrm{cm}^{-2}$.

Preparation of the PI/CNT anode. PI-based organic anodes were prepared following a similar protocol as mentioned above; however, the difference is the use of an additional electrode component, PVDF as the binder. The mass ratio of PI : CNT : PVDF was $6: 3: 1$, and the loading of PI was about $1.5 \mathrm{mg} \mathrm{cm}^{-2}$.

\section{PI-PC full-cell fabrication}

PI-PC full-cells were assembled using circular discs $(12 \mathrm{~mm}$ diameter) of PI/CNTs as the anode, PC/CNTs as the cathode, and a pair of porous Whatman® glass microfiber filters (Grade GF/B) soaked with $\sim 200 \mu \mathrm{L}$ of electrolyte in CR2032 coin cells. The mass ratio between PI and PC was $1: 1,1: 0.9,1: 0.7$, and $1: 0.72$ in $\mathrm{Li}^{+}, \mathrm{Zn}^{2+}, \mathrm{Al}^{3+}$, and $\mathrm{Li}^{+} / \mathrm{H}^{+}$configurations, respectively, according to the capacities of individual electrodes in the three-electrode investigations. The aqueous electrolytes for $\mathrm{Li}^{+}$, $\mathrm{Zn}^{2+}$ and $\mathrm{Al}^{3+}$ ion batteries were prepared by dissolving $\mathrm{LiNO}_{3}$, $\mathrm{ZnSO}_{4}$ or $\mathrm{Al}\left(\mathrm{NO}_{3}\right)_{3}$ in degassed milli-Q water to a $2.5 \mathrm{M}$ concentration. The mixed aqueous electrolyte $\left(\mathrm{Li}^{+} / \mathrm{H}^{+}\right)$was composed of 2.5/0.25 $\mathrm{M} \mathrm{LiNO}_{3} / \mathrm{H}_{2} \mathrm{SO}_{4}$. The cells were assembled in a high-purity argon-filled glovebox (MBraun; $\mathrm{O}_{2}<0.5 \mathrm{ppm}$ ) to avoid any possible contamination by oxygen.

\section{Electrochemical characterization}

The electrochemical performance of individual electrodes and full-cells was investigated by cycling voltammetry (CV) and galvanostatic charge-discharge (GCD) experiments using a Biologic VMP3 multichannel Potentiostat/Galvanostat (Biologic SP150). The CV and GCD profiles of redox-active polymers (RAPs) were obtained using a flooded three-electrode electrochemical cell with RAP/CNT ink (80/20 wt\%) modified glassy carbon (GC, with an area of $\left.0.07 \mathrm{~cm}^{2}\right), \mathrm{Ag} / \mathrm{AgCl}(\mathrm{KCl}$ sat.) and platinum wire as the working, reference and counter electrodes, respectively, in different aqueous electrolytes. The electrolyte was degassed with argon, and CV/GCD was performed at room temperature under a positive pressure of argon atmosphere. The real-time evolution of individual voltages of electrode partners in fullcells was assessed with Swagelok ${ }^{\mathrm{TM}}$ T-cells, in which PI, PC, and $\mathrm{Ag} / \mathrm{AgCl}$ ( $\mathrm{KCl}$ sat.) were used as the anode, cathode and reference electrode, respectively. As control experiments, the CV analysis of PC electrodes was also carried out in aqueous citrate buffer solutions $(\mathrm{pH}=5)$ and organic electrolytes (anhydrous DMF) containing $\mathrm{Li}^{+}$(from LiTFSI), $\mathrm{Zn}^{2+}$ (from $\mathrm{Zn}(\mathrm{TFSI})_{2}$ ), and $\mathrm{Al}^{3+}$ (from $\mathrm{Al}(\mathrm{TFSI})_{3}$ ) charge carriers. $\mathrm{Ag}$ wire was used as a pseudo-reference electrode in organic electrolytes.

Theoretical specific capacity ( $\mathrm{mA} \mathrm{h} \mathrm{g}^{-1}$ ) was calculated using the equation $=\left(26801 \times n \times w_{\mathrm{RA}}\right) / \mathrm{MW}_{\mathrm{RA}}$, where $n$ is the 
number of electrons exchange per unit of catechol/o-quinone ( $n$ $=2$ ), and $w_{\mathrm{RA}}$ and $\mathrm{MW}_{\mathrm{RA}}$ and are the weight fraction and the molecular weight of redox-active (RA) units, respectively. ${ }^{42}$ The theoretical specific capacity of PC and PI is about 180 and $166 \mathrm{~mA} \mathrm{~h} \mathrm{~g}^{-1}$, respectively. The energy density $\left(\mathrm{W} \mathrm{h} \mathrm{kg}^{-1}\right)$ of the full-cell was determined by integrating the area under the galvanostatic specific capacity anode+cathode $^{- \text {voltage discharge }}$ profiles. Power density $\left(\mathrm{W} \mathrm{kg}^{-1}\right)$ was calculated as (energy density/discharge time) $\times 3600$.

\section{Computational method}

The structure of the PI and PC polymers is truncated to a simple monomer structure that is composed of naphthalenetetracarboxylic diimide (NDI) substituted with a $-\mathrm{CH}_{3}$ group at the nitrogen position and a catecholate (CAT) moiety, respectively. The lithium, zinc and aluminum cations are considered to have their first coordination sphere filled with 4, 6 and 6 explicit water molecules, respectively. The binding free energies of the solvated metal cations are calculated with respect to the reduced form of the catecholate/imide monomer moieties from the following equation: $[\mathrm{MON}]^{2-}+y\left[\mathrm{M}\left(\mathrm{H}_{2} \mathrm{O}\right)_{x}\right]^{m+} \rightarrow[\mathrm{MON}-$ $\left.\mathrm{M}_{y}\left(\mathrm{H}_{2} \mathrm{O}\right)_{n x-z}\right]^{y m-2}+z\left(\mathrm{H}_{2} \mathrm{O}\right)$, where MON is the catecholate or imide species. The absolute redox potentials are calculated from: $E=-\Delta G_{\mathrm{rxn}} /(2 F)$, where $\Delta G_{r x n}$ is the free energy change for the $2 \mathrm{e}^{-}$-reduction reaction: $[\mathrm{MON}]+2 \mathrm{e}^{-}+y\left[\mathrm{M}\left(\mathrm{H}_{2} \mathrm{O}\right)_{x}\right]^{m+} \rightarrow$ $\left[\mathrm{MON}-\mathrm{M}_{y}\left(\mathrm{H}_{2} \mathrm{O}\right)_{n x-z}\right]^{y m-2}+z\left(\mathrm{H}_{2} \mathrm{O}\right)$. Full details of the computational protocol are presented in the $\mathrm{ESI} \dagger$ and are taken from our previous work. ${ }^{41}$

\section{Results and discussion}

\section{Effect of charge carriers on the electrochemical response}

Redox response of individual electrodes with $\mathrm{Li}^{+}, \mathrm{Zn}^{2+}$, and $\mathbf{A l}^{3+}$ as charge carriers. The redox reactions in both anode and cathode redox polymers were probed by cyclic voltammetry $(\mathrm{CV})$ in a three-electrode cell using aqueous electrolytes containing different charge carriers, such as $\mathrm{Li}^{+}, \mathrm{Zn}^{2+}$ and $\mathrm{Al}^{3+}$. The poly(imide) (PI) anode (see Fig. 1a for the chemical structure) in the $\mathrm{Li}^{+}$containing aqueous electrolyte demonstrated two successive redox processes with average peak potentials, $E_{1 / 2}\left(\left[E_{\mathrm{p}, \mathrm{a}}+E_{\mathrm{p}, \mathrm{c}}\right] / 2\right)$ located at $E_{\mathrm{PI}, 1} \approx-0.26 \mathrm{~V}$ and $E_{\mathrm{PI}, 2} \approx-0.73 \mathrm{~V}$ (Fig. $1 \mathrm{~b}$, top panel). These redox peaks correspond to the transformation of $\mathrm{PI}$ into $\mathrm{PI}^{\cdot-}\left[1 \mathrm{Li}^{+}\right]$and then into $\mathrm{PI}^{2-}\left[2 \mathrm{Li}^{+}\right]$to give n-doped states through conjugated carbonyl groups with concomitant electroneutralization by $\mathrm{Li}^{+}$during the reduction sweep (Fig. 1a). ${ }^{33,35,44-46}$ The reverse reaction occurs in the subsequent oxidation sweep with the expulsion of $\mathrm{Li}^{+}$from the enolate sites. Therefore, the overall redox reaction of PI can be considered as a quasi-reversible two successive one-electron process with an average conversion potential of $E_{\text {ave } \mathrm{PI}, \mathrm{Li}^{+}} \approx-0.5 \mathrm{~V}$. Here the term $E_{\text {ave }}\left(\left[E_{\mathrm{PI}, 1}+E_{\mathrm{PI}, 2}\right] / 2\right)$ is just used as the average conversion potential for a two successive one-electron process with the purpose of representing the anticipated voltage output of the full-cell when coupled with a positive electrode and should not be confused with the usage of $E_{1 / 2}$. Interestingly, when the $\mathrm{Li}^{+}$ charge carriers were substituted by divalent $\mathrm{Zn}^{2+}$ and trivalent $\mathrm{Al}^{3+}$, the PI exhibited similar electrochemical features; however, the redox processes appeared at slightly more positive potentials, i.e., $E_{\text {ave PI,Zn }}{ }^{2+} \approx-0.47 \mathrm{~V}$ and $E_{\text {ave PI, } \mathrm{Al}^{3+}} \approx-0.40 \mathrm{~V}$ (see Fig. 1a for the schematic representation and Fig. 1b for CVs).

On the other hand, the poly(catechol) cathode (PC) (see Fig. 1c for the chemical structure) featured a single redox process corresponding to an anodic peak of $\mathrm{PC}^{2-}\left[2 \mathrm{Li}^{+}, 1 \mathrm{Zn}^{2+}\right.$ or $\left.1 \mathrm{Al}^{3+}\right]$ to PQ (PQ refers to poly(ortho-quinone) transformation) and a cathodic peak of $\mathrm{PQ}$ to $\mathrm{PC}^{2-}\left[2 \mathrm{Li}^{+}, 1 \mathrm{Zn}^{2+}\right.$ or $\left.1 \mathrm{Al}^{3+}\right]$ conversions. The CVs in Fig. 1b evidenced the quasi-reversible nature of this two- $\mathrm{Li}^{+}$(one- $\mathrm{Zn}^{2+}$ or one- $\mathrm{Al}^{3+}$ ) and two-electron process. ${ }^{41}$ Importantly, differently from the PI, the average peak potentials of $\mathrm{PC}$ were dramatically shifted positive (i.e., $E_{\mathrm{PC}, \mathrm{Li}^{+}} \approx 0.1 \mathrm{~V}, E_{\mathrm{PC}, \mathrm{Zn}}{ }^{2+} \approx 0.28 \mathrm{~V}$, and $\left.E_{\mathrm{PC}, \mathrm{Al}^{3+}} \approx 0.51 \mathrm{~V}\right)$, in the
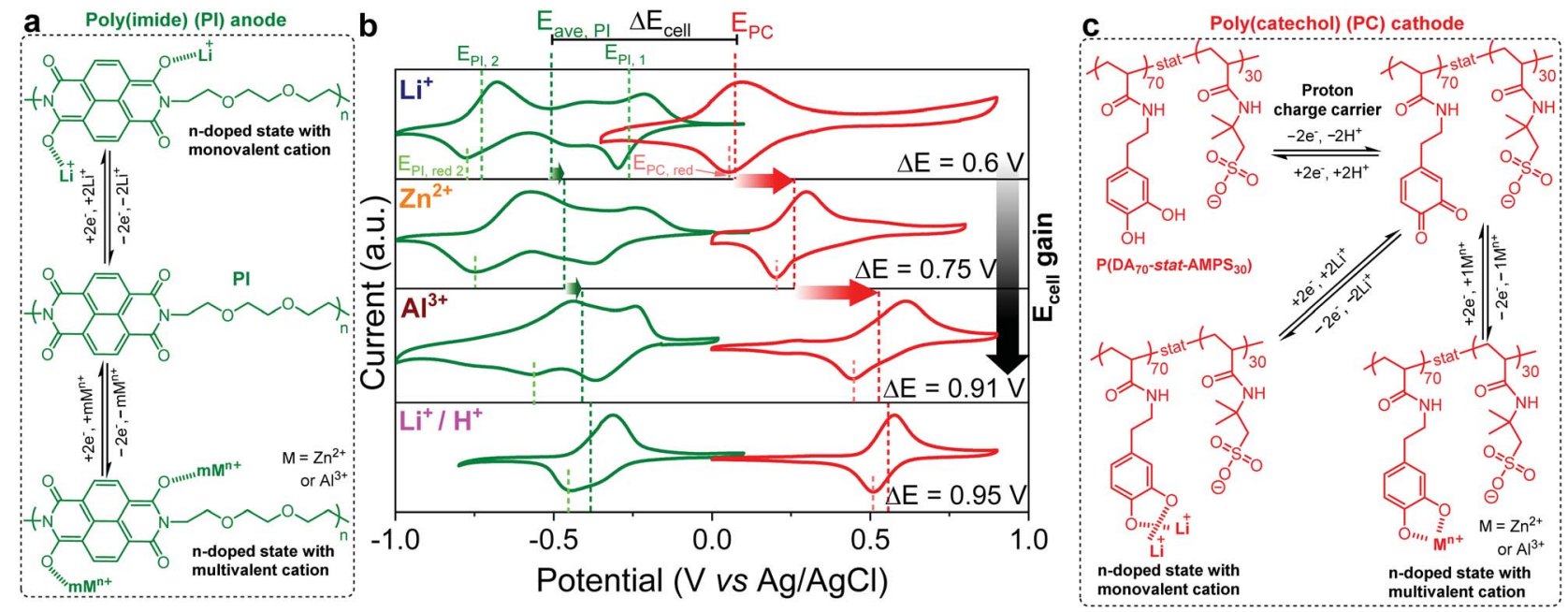

Fig. 1 ( $a$ and c) Schematic representation of the $n$-type redox behavior of PI (a) and PC (c) with both mono- and multivalent cations. (b) Cyclic voltammograms of PI (profiles in green) and PC (profiles in red) half-cells in unbuffered aqueous electrolytes containing different charge carriers, i.e., $\mathrm{Li}^{+}, \mathrm{Zn}^{2+}, \mathrm{Al}^{3+}$, and $\mathrm{Li}^{+} / \mathrm{H}^{+}$(top to bottom). The $\mathrm{CVs}$ were recorded at $10 \mathrm{mV} \mathrm{s}{ }^{-1}$ in a standard three-electrode configuration. 
same order of electroneutralizing cation valences $\left(\mathrm{Li}^{+}<\mathrm{Zn}^{2+}<\right.$ $\mathrm{Al}^{3+}$ ), as previously reported by our group. ${ }^{41}$

Although the electrochemical analysis was carried out in unbuffered aqueous electrolytes containing different charge carriers, it was recently demonstrated by our group that the reduction/oxidation of ortho-quinones/catecholates in similar electrolytes occurs via the coordination/uncoordination of cations of the supporting salts. ${ }^{41}$ Very recently, Yan et al. ${ }^{47}$ and Wang et $a{ }^{48}$ have demonstrated a similar redox mechanism with anthraquinone and quinone compounds, respectively. Additionally, this redox reaction mechanism with the coordination/uncoordination of designated metal cations has been also well proven for both PC and PI elsewhere in the context of metal-ion aqueous batteries. ${ }^{34-40}$

The reduction of ortho-quinones into catecholates and the subsequent n-type coordination reaction depend not only on the $\mathrm{pH}$ of the aqueous electrolyte, but also on the nature and concentration of cationic charge carriers. ${ }^{49}$ As control experiments, we accomplished CV analysis of PC in both aqueous citrate buffer solutions ( $\mathrm{pH}=5$; Fig. 2a) and aprotic organic electrolyte media (Fig. 2b) containing $\mathrm{Li}^{+}, \mathrm{Zn}^{2+}$, and $\mathrm{Al}^{3+}$ charge carriers, separately, which revealed a similar shift of redox potential in the $\mathrm{Li}^{+}<\mathrm{Zn}^{2+}<\mathrm{Al}^{3+}$ order. Notably, the latter results are in line with the recent study by Svensson et al., who elucidated the redox mechanism of quinone and catechol redox polymers in organic electrolytes containing different charge carriers. ${ }^{50}$ It is worth mentioning that besides the main redox peak associated with the coordination/uncoordination of $\mathrm{Li}^{+}$, the $\mathrm{CV}$ of PC in a slightly acidic $\mathrm{Li}^{+}$buffer solution (Fig. 2a) also shows a small peak at higher potential which might be attributed to the contribution of protons to the redox mechanism. Interestingly, this second peak does not appear in the CV of PC in a neutral $\mathrm{Li}^{+}$containing aqueous electrolyte (see Fig. 1b). These results suggest that the neutral $\mathrm{pH}$ favours $\mathrm{Li}^{+}$cycling, whereas under slightly acidic conditions both protons and lithium ions might be involved. Furthermore, the involvement of different charge carriers $\left(\mathrm{Li}^{+}, \mathrm{Zn}^{2+}\right.$ or $\left.\mathrm{Al}^{3+}\right)$ in the redox reaction of PC was confirmed here by ex situ ATR FTIR experiments (Fig. 2c), where the stretching vibration of the catecholic $\mathrm{C}=\mathrm{O}$ bond at $\sim 1650 \mathrm{~cm}^{-1}$ becomes discernible upon electrochemical oxidation but its intensity significantly decreased upon reduction. Parallelly, the evolution of a characteristic catecholate stretching band below $1200 \mathrm{~cm}^{-1}$ upon the formation of catecholic $\mathrm{C}^{-} \mathrm{O}^{-} \cdots \mathrm{M}^{n+}\left(\mathrm{M}^{n+}=\mathrm{Li}^{+}, \mathrm{Zn}^{2+}\right.$ or $\left.\mathrm{Al}^{3+}\right)$ during the reduction was also evident and different from proton reduction. Interestingly, its red shift in the $\mathrm{Li}^{+}\left(1202 \mathrm{~cm}^{-1}\right)<\mathrm{Zn}^{2+}$ $\left(1106 \mathrm{~cm}^{-1}\right)<\mathrm{Al}^{3+}\left(1029 \mathrm{~cm}^{-1}\right)$ order indicates stronger interaction of $\mathrm{M}^{n+}$ with ${\mathrm{C}-\mathrm{O}^{-}}^{-}$in the same order of metal cation valences. $^{40,51}$ Taken together, these results confirm that the cations of the supporting electrolytes are mainly involved in the electrochemical reaction. However, despite all those control experiments, we cannot completely exclude the involvement of protons on the redox mechanism in acidic electrolytes and further studies would be necessary to undoubtedly elucidate this aspect.

Using a mixed electrolyte as a strategy to boost the voltage further. In order to maximize the cell voltage, the potential of the anode and the cathode should be kept as low (negative) and as high (positive) as possible, respectively. Thanks to the distinguishing voltage characteristics of PI and PC, all-organic fullcells with increasing voltage in the $\mathrm{Li}^{+}<\mathrm{Zn}^{2+}<\mathrm{Al}^{3+}$ order can be anticipated (Fig. 1b and Table 1). It is worth mentioning here that chemical manipulation, ${ }^{55-57} \pi$-conjugation adaptivity ${ }^{58,59}$ and spectator cation substitution in the host structure ${ }^{60}$ approaches are most often used to tune the redox potentials of the organic core. Negatively, such strategies also add deadweight to the active materials, which might penalize the specific capacity as well. However, in this work we realize voltage tunability of all-organic cells without modifying the redox core structure.

In this sense, it is well-known that catechols also undergo ortho-quinone/catechol redox transformations via a protoncoupled two-electron process (Fig. 1c) at significantly high redox potentials. ${ }^{61-63}$ Therefore, to boost the voltage output of the PI-PC full-cell further we explored the mixed electrolyte concept (containing $\mathrm{Li}^{+}$and $\mathrm{H}^{+}$). ${ }^{25}$ Fig. $1 \mathrm{~b}$ (lower panel) shows the CVs of PI and PC in such a mixed electrolyte anticipating a maximum voltage output of $0.95 \mathrm{~V}_{\text {with }} \mathrm{H}^{+}$and $\mathrm{Li}^{+}$involved in
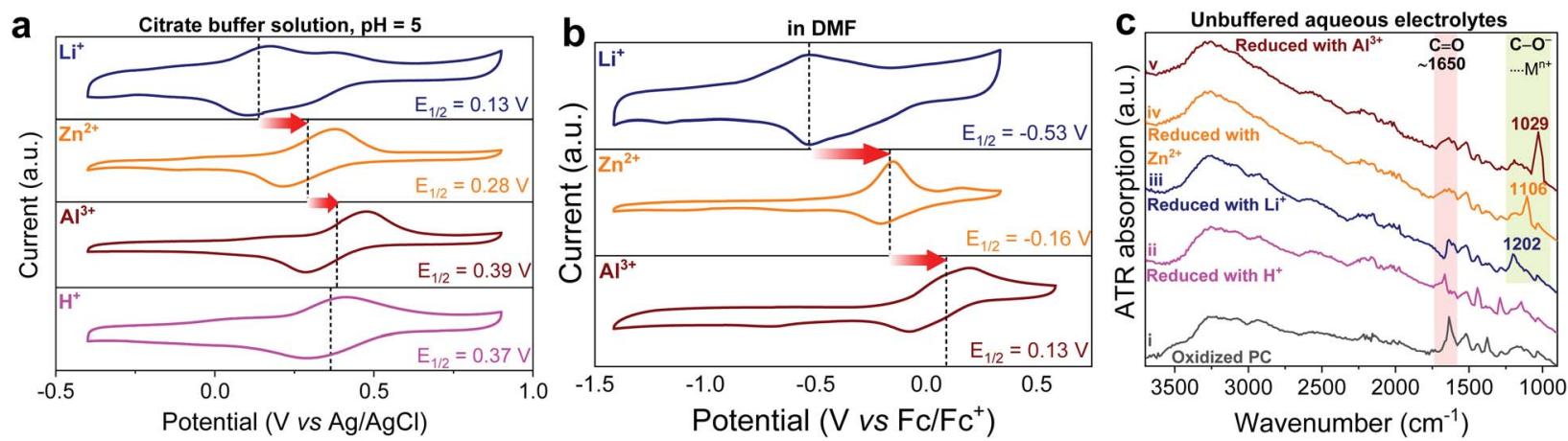

Fig. 2 (a) Cyclic voltammograms of PC in (a) aqueous citrate buffer solutions ( $\mathrm{pH}=5$ ) and (b) organic electrolytes (anhydrous DMF). The CVs were recorded at $5 \mathrm{mV} \mathrm{s}^{-1}$ in a standard three-electrode configuration. Potentials in Fig. $2 \mathrm{~b}$ were later corrected with the ferrocene/ferrocenium (Fc/Fc ${ }^{+}$) redox couple. (c) Vertically offset ex situ ATR-FTIR spectra of oxidized PC(i) and reduced PC with $\mathrm{H}^{+}$(ii), $\mathrm{Li}^{+}$(iii), $\mathrm{Zn}^{2+}$ (iv), and $\mathrm{Al}^{3+}$ (v) in the aqueous unbuffered electrolytes. 
Table 1 Experimental and modelling parameters for PI and PC in unbuffered aqueous electrolytes

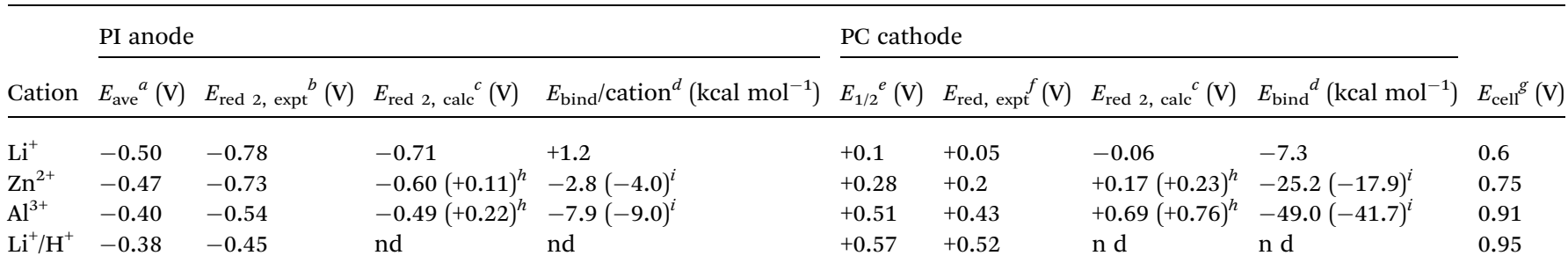

${ }^{a}$ Average conversion potential $\left(E_{\mathrm{ave}}\right)=\left(E_{\mathrm{PI}, 1}+E_{\mathrm{PI}, 2}\right) / 2$ measured at $10 \mathrm{mV} \mathrm{s}{ }^{-1} \cdot{ }^{b} E_{\mathrm{red} 2 \text {, exp }}$ obtained experimentally at $10 \mathrm{mV} \mathrm{s}{ }^{-1} \cdot{ }^{c}$ Refer to the ESI to see the full details of the computational method to calculate $E_{\text {red 2, calc. }}{ }^{d}$ Refer to the ESI to see the full details of the computational method to calculate $E_{\text {binding }}$ per cation. ${ }^{e}$ Average peak potential $\left(E_{1 / 2}\right)=E_{\text {anodic peak }}+E_{\text {cathodic peak }} / 2$ measured at $10 \mathrm{mV} \mathrm{s}^{-1} .{ }^{f} E_{\text {red, }}$ exp obtained experimentally at $10 \mathrm{mV} \mathrm{s}^{-1} \cdot{ }^{g} E_{\text {cathode }}\left(E_{1 / 2}\right)-E_{\text {anode }}\left(E_{\text {ave }}\right)$ at $10 \mathrm{mV} \mathrm{s}^{-1}$. All the potentials (in CV and DFT calculations) are referenced against $\mathrm{Ag} / \mathrm{AgCl} .{ }^{h}$ Relative reduction potential gain of active materials for binding with $\mathrm{Zn}^{2+}$ or $\mathrm{Al}^{3+}$ compared to $\mathrm{Li}^{+} .{ }^{i} \mathrm{Change}^{3}$ in the binding energy of active materials with $\mathrm{Zn}^{2+}$ or $\mathrm{Al}^{3+}$ in the reduced state compared to that with $\mathrm{Li}^{+} . \mathrm{n} \mathrm{d}=$ not determined.

the electrochemistry of the PC cathode and PI anode, respectively. It should be noted that achieving AqPBs with an output voltage above $0.9 \mathrm{~V}$ is not that simple task, particularly for the $\mathrm{n} \mid \mathrm{n}$-type combination (Table S1†). We did not consider proton cycling in the case of PI because to the best of our knowledge, imides are not known to undergo proton coupled redox reactions. Evidently, Gheytani et al. demonstrated the $\mathrm{pH}$ independent redox activity of PI in aqueous electrolytes. ${ }^{35}$

Quantum chemical calculations. In order to elucidate the difference in redox potentials for PI and PC, we looked into the electronic structure of imide/enolate and catecholate/orthoquinone repeating units to calculate the second-reduction potential $\left(E_{\text {red 2, calc }}\right)$ and binding free energy $\left(E_{\text {bind }}\right)$ using quantum-chemical calculations based on density functional theory (DFT) (see details in the ESI $\uparrow$ ). From Table 1, it can be seen that there is a good correlation between the experimental and the calculated reduction potentials for both imide and ortho-quinone moieties in the presence of $\mathrm{Li}^{+}, \mathrm{Zn}^{2+}$ and $\mathrm{Al}^{3+}$ charge carriers.

Analogues to the CV observations, a distinctive small and huge increase of $E_{\text {red 2, calc }}$ in the order of $\mathrm{Li}^{+}<\mathrm{Zn}^{2+}<\mathrm{Al}^{3+}$ was accounted for PI and PC, respectively. Assuming the similar redox mechanism of both PI and PC based on their $n$-type nature, the difference in redox potentials should be ascribed to the differences in strength of metal cation-reduced redox core interactions $\left(E_{\text {bind }}\right)$. The computed $E_{\text {bind }}$ between enolate (of PI) and $\mathrm{Li}^{+}, \mathrm{Zn}^{2+}$ and $\mathrm{Al}^{3+}$ was $+1.2,-2.8$, and $-7.9 \mathrm{kcal} \mathrm{mol}^{-1}$ per cation, respectively (Table 1). However, a higher $E_{\text {bind }}$ of -7.3 , -25.2 , and $-49.0 \mathrm{kcal} \mathrm{mol}^{-1}$ per cation was obtained for metal cation-catecholate (of PC) with $\mathrm{Li}^{+}, \mathrm{Zn}^{2+}$ and $\mathrm{Al}^{3+}$, respectively. In general, a higher value of $E_{\text {bind }}$ is associated with larger positive shifts in reduction potentials due to the enhanced thermodynamic stabilization of the reduced species into the complexes, ${ }^{41,47,50}$ and thus their re-oxidation becomes increasingly difficult and occurs at more positive potentials in the $\mathrm{Li}^{+}<$ $\mathrm{Zn}^{2+}<\mathrm{Al}^{3+}$ order. Therefore, a small enhancement by -4.0 and $-9.0 \mathrm{kcal} \mathrm{mol}^{-1}$ in $E_{\text {bind }}$ induced a minute increase of redox potential for enolate (PI) with $\mathrm{Zn}^{2+}$ and $\mathrm{Al}^{3+}$, respectively, compared to $\mathrm{Li}^{+}$, whereas, a huge increase in redox potential for catecholate (PC) was linked to the large increment of $E_{\text {bind }}$ (by -17.9 and $-41.7 \mathrm{kcal} \mathrm{mol}^{-1}$ for $\mathrm{Zn}^{2+}$ and $\mathrm{Al}^{3+}$, respectively, compared to $\mathrm{Li}^{+}$). This distinctive trend in $E_{\text {bind }}$ and thus redox potential between PI and PC are presumably due to their different electron density. Localized electron density on the catecholate ring and the ortho-nature of quinone redox sites lead to strong metal-polymer interactions in PC, ${ }^{52,53}$ while for PI the para-oriented redox-active enolates and more diffused electron density over the extended naphthalenetetracarboxylic diimide (NDI) ring result in weaken metal-polymer interactions. ${ }^{54}$

\section{Electrochemical performance of individual electrodes}

Fig. 3 shows the rate performance of PI and PC half-cells by GCD experiments at progressively increasing C-rates in different aqueous electrolytes containing $\mathrm{Li}^{+}, \mathrm{Zn}^{2+}, \mathrm{Al}^{3+}$, and $\mathrm{Li}^{+} / \mathrm{H}^{+}$ charge carriers.

The representative specific capacity-potential profiles are given in the ESI (Fig. S4 and S5†). It is also evident from these potential profiles that despite their sloping nature, the charge/ discharge plateaus of PI and PC were shifted to higher values in the $\mathrm{Li}^{+}<\mathrm{Zn}^{2+}<\mathrm{Al}^{3+}$ order, but to a different extent, which is in good agreement with CV studies and DFT calculations. Both PI and PC delivered reversible capacities in the range of 128$164 \mathrm{~mA} \mathrm{~h} \mathrm{~g}^{-1}$ and $167-183 \mathrm{~mA} \mathrm{~h} \mathrm{~g}^{-1}$, respectively, at $2 \mathrm{C}$ in the aforementioned electrolytes (Fig. 3a). PI in $\mathrm{Li}^{+}$provided the highest discharge capacity of $164 \mathrm{~mA} \mathrm{~h} \mathrm{~g}{ }^{-1}$, close to the theoretical limit $\left(166 \mathrm{~mA} \mathrm{~h} \mathrm{~g}^{-1}\right)$. However, lower capacity utilization values of 93, 86 and $77 \%$ were obtained in $\mathrm{Zn}^{2+}, \mathrm{Al}^{3+}$, and $\mathrm{Li}^{+} / \mathrm{H}^{+}$, respectively. Notably, the coulombic efficiencies were close to $100 \%$ in all the cases (Fig. S4 $\dagger$ ). On the other hand, PC demonstrated a better active-material utilization in the range of 93-100\% (theoretical specific capacity of $180 \mathrm{~mA} \mathrm{~h} \mathrm{~g}^{-1}$ ) but lower coulombic efficiencies at low C-rates, and subsequently recovered to the quantitative values at higher C-rates (Fig. S5 $\dagger$ ).

With increasing C-rates from $2 \mathrm{C}$ to $240 \mathrm{C}$, both the discharge capacities (Fig. 3a) and consequently the capacity retentions (capacities at higher C-rates w.r.t. the capacity at 2C; Fig. 3b) of PI and PC decreased monotonically in the $\mathrm{Li}^{+}<\mathrm{Zn}^{2+}<\mathrm{Al}^{3+}$ order. As demonstrated in our previous publication, ${ }^{41}$ this diminished rate performance should be ascribed to the sluggish ion mobilities on account of stronger metal cation-polymer interactions in the same order of charge carrier valences. 

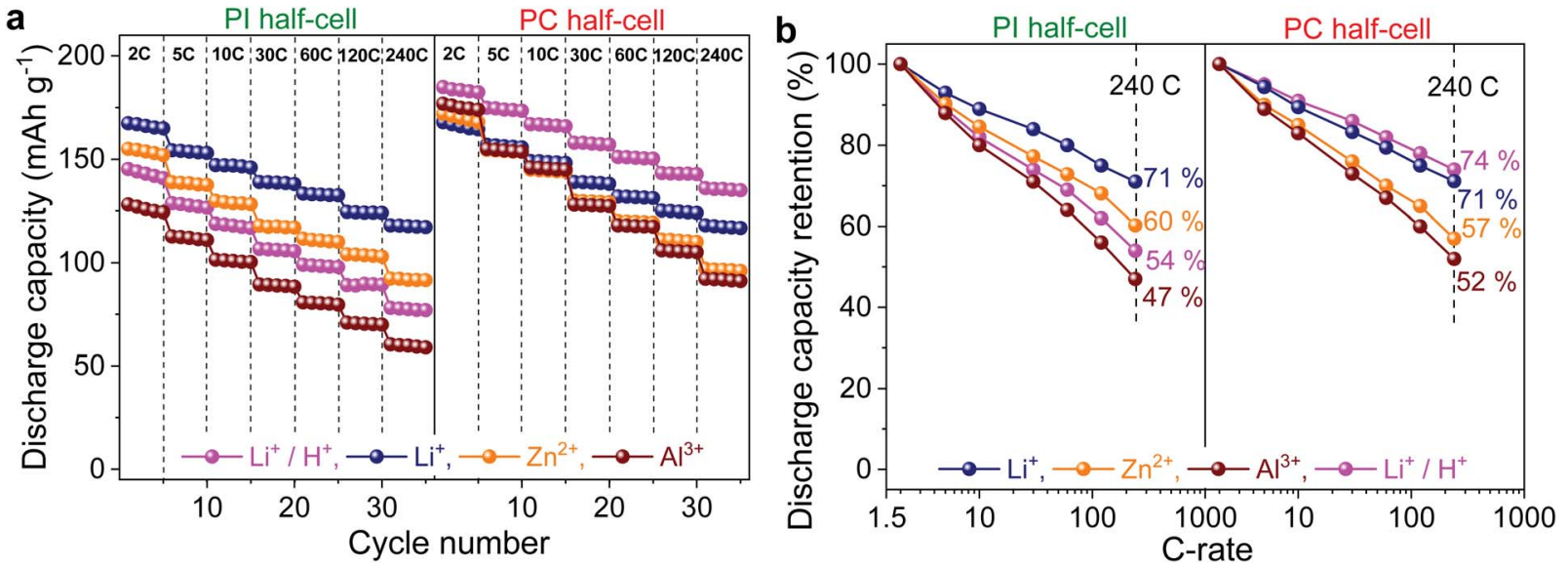

Fig. 3 (a) Discharge capacity vs. cycle number at increasing C-rates. (b) Discharge capacity retention at different C-rates. The discharge capacities at higher $\mathrm{C}$-rates are normalized with respect to the discharge capacity at $2 \mathrm{C}\left(1 \mathrm{C}=166\right.$ and $180 \mathrm{~mA} \mathrm{~g}^{-1}$ for $\mathrm{PI}$ and $\mathrm{PC}$, respectively).

Remarkably, even at a very high C-rate of 240C, PI and PC still retained 71,60 and $47 \%$ and 71,57 and $52 \%$ of their initial capacities in $\mathrm{Li}^{+}, \mathrm{Zn}^{2+}$ and $\mathrm{Al}^{3+}$, respectively. Additionally, both the electrode partners of the all-organic cell also demonstrated excellent dynamic performance in the $\mathrm{Li}^{+} / \mathrm{H}^{+}$electrolyte, but the overall performance of PC was superior to that of PI (Fig. 3).

In order to understand the origin of the outstanding rate performance of PI and PC, the electrochemical kinetics of redox reactions in polymer working electrodes were investigated by $\mathrm{CV}$ at different scan rates $(v)$ in the aqueous electrolyte containing $\mathrm{Li}^{+}$as the representative charge carrier. The Laviron method was used to determine the transfer coefficient $(\alpha)$ and apparent reaction rate constant $\left(k^{0}\right)$ parameters (Fig. 4a, d and S6†). ${ }^{64}$ The value of $\alpha$ was close to 0.5 for both systems, indicating almost symmetric energy barriers for the oxidation and reduction reactions. Furthermore, the calculated $k^{0}$ was found
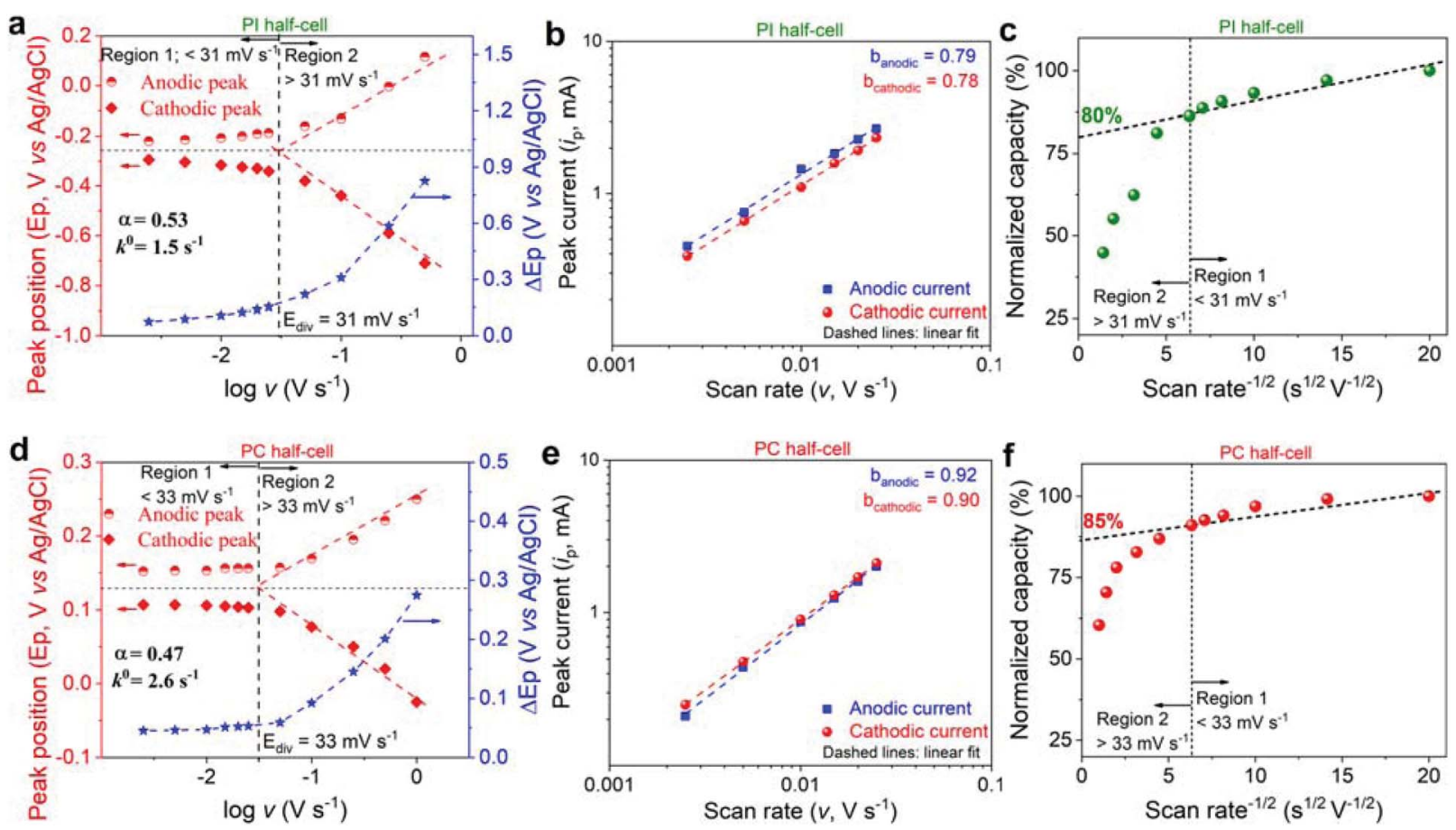

Fig. 4 Kinetic evaluation of PI and PC half-cells. (a and d) Laviron plots, indicating the variation of anodic and cathodic peak positions ( $E_{\mathrm{p}}$ ), and $\Delta E_{\mathrm{p}}$ as a function of the scan rate on a logarithmic scale. ( $\mathrm{b}$ and e) Plots of peak current vs. scan rate on a logarithmic scale. (c and f) Normalized capacity vs. scan rate ${ }^{-1 / 2}$ plots. The dashed vertical line in ( $a, c, d$ and f) separates two distinct kinetic regions: Region 1 below $E_{\text {div }}$ where the capacity is mostly independent of the scan rate, and region 2 above $E_{\text {div }}$ where the capacity is limited by semi-infinite linear diffusion. The $y$ -

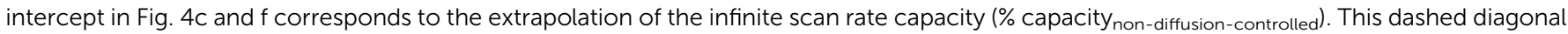
line is drawn based on the two distinct kinetic regions. 
to be 1.5 and $2.6 \mathrm{~s}^{-1}$ for PI and PC, respectively. Additionally, considering that the peak currents $\left(i_{\mathrm{p}}\right)$ in the CV curves obey the power-law relationship as: $i_{\mathrm{p}}=\mathrm{a} v^{\mathrm{b}}$, where $a$ and $b$ are adjustable coefficients, the slope ( $b$-value) of the $\log \left(i_{\mathrm{p}}\right)$ vs. $\log (v)$ plot provides insights into the underlying redox mechanism. ${ }^{65}$ Ideally, the $b$-value of 0.5 indicates a diffusion-controlled process, whereas the $b$-value of 1.0 is the signature of a capacitive-controlled behavior.

High $b$-values of $0.79 / 0.78$ and $0.92 / 0.90$ for the anodic/ cathodic peaks were obtained for PI and PC (Fig. 4b and e), respectively, suggesting a mixed electrochemical response but tending to be less diffusion limited. Here, the capacitive-type electrochemical response is assumed to have mainly originated from bulk electrochemical reaction sites (similar to intercalation pseudocapacitance that is observed in some inorganic intercalation compounds, which is different from conventional surface pseudocapacitance in nanomaterials) ${ }^{65-67}$ that are less limited by the diffusion processes on account of polymer's high reaction rates and superior ion mobilities. ${ }^{41-43}$ To further quantify the contributions of diffusion- and nondiffusion-controlled charge storage to the total capacity, the correlation between normalized capacity and $v^{-1 / 2}$ was estab-

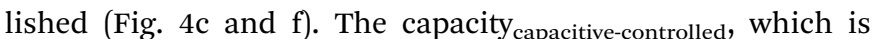
non-diffusion limited, was obtained as the $y$-intercept, ${ }^{65}$ resulting in 80 and $85 \%$ for PI and PC, respectively, resembling a fast pseudocapacitive behavior. Thanks to the smart design of both the electrode partners, they are engineered to exhibit pseudo-capacitive like energy storage behavior on account of fast redox reactions and facilitated ion-mobility in the bulk of the material. In fact, the incorporation of ion conducting 2acrylamido-2-methylpropane sulfonate ${ }^{42}$ and poly(ethylene oxide $)^{\mathbf{4 3}}$ comonomer moieties in PC and PI, respectively, assisted the ion transport. Therefore, superior rate performance is anticipated for the PI-PC full-cells.

It is worth noting that both PI and PC demonstrated satisfactory stable cycling over 100 GCD cycles at 10C, retaining 98, 97, 91, and 98\% (Fig. S7†) and 96, 95, 94, and 94\% (Fig. S8 $\dagger$ ) of their initial capacities, respectively, with quantitative coulombic efficiencies (>99\%) in $\mathrm{Li}^{+}, \mathrm{Zn}^{2+}, \mathrm{Al}^{3+}$, and $\mathrm{Li}^{+} / \mathrm{H}^{+}$.

\section{Electrochemical performance evaluation of PI-PC all-organic batteries}

Based on the excellent electrode performance of PI and PC individual electrodes, along with their tunable voltage behaviors, all-organic aqueous rechargeable batteries were assembled with PI and PC serving as the anode and cathode, respectively. A schematic illustration of the full-cell structure and the overall electrode reactions of the cells in two different sets of aqueous electrolytes are given in Scheme 1.

The full-cells operate in a cationic rocking-chair mode in $\mathrm{Li}^{+}$, $\mathrm{Zn}^{2+}$ or $\mathrm{Al}^{3+}$ based electrolytes, with unidirectional shuttling of charge carriers from the anode to the cathode during discharge (Scheme 1a) and from the cathode to the anode during charge. ${ }^{18}$ On the other hand, the PI-PC full-cell is assumed to operate in a non-rocking chair cationic hybrid-ion configuration with a mixed $\mathrm{Li}^{+} / \mathrm{H}^{+}$electrolyte: during the discharging process,

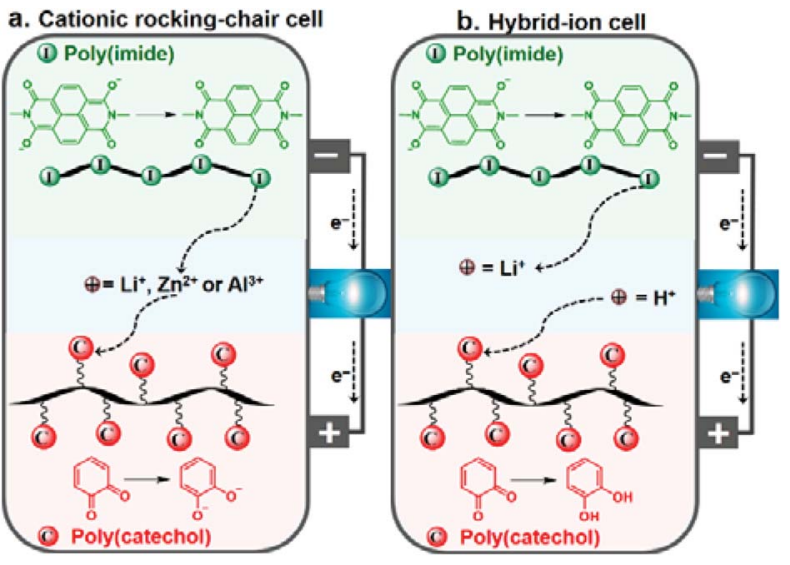

Scheme 1 Schematic of the working principle of the PI-PC full-cell during the discharge process in a cationic rocking-chair mode with $\mathrm{Li}^{+}$, $\mathrm{Zn}^{2+}$ or $\mathrm{Al}^{3+}(\mathrm{a})$, and hybrid-ion configuration with $\mathrm{Li}^{+} / \mathrm{H}^{+}$(b).

enolates are oxidized to imides while releasing $\mathrm{Li}^{+}$into the electrolyte reservoir, and ortho-quinones are reduced to the classical catechols with the uptake of $\mathrm{H}^{+}$from the electrolyte (Scheme 1b). ${ }^{25}$ Conversely, catechols are oxidized to orthoquinones, while $\mathrm{H}^{+}$reversibly breaks away from the cathode and return to the electrolyte, and the imides are reduced to enolates with the concomitant coordination of $\mathrm{Li}^{+}$. However, the interaction of $\mathrm{H}^{+}$with PI in the $\mathrm{Li}^{+} / \mathrm{H}^{+}$mixed electrolyte can be argued, and we partially discard this through the following controlled experiment. When PI was cycled in $0.25 \mathrm{M} \mathrm{H}_{2} \mathrm{SO}_{4}$, the electrochemical stability rapidly diminished upon cycling, indicating its poor compatibility with protons (Fig. S9†), which was already reported by Wang et al. ${ }^{68}$ Encouragingly, the cycling stability of the PI half-cell (Fig. S7e $\dagger$ ) and PI-PC full-cell (discussed later, shown in Fig. $5 \mathrm{c}$ ) in $\mathrm{Li}^{+} / \mathrm{H}^{+}$significantly improved compared to only in $\mathrm{H}^{+}$, once again suggesting that $\mathrm{Li}^{+}$is involved in the redox reaction of PI.

The mass ratio between PI and PC in the full-cell was calculated to be $1: 1,1: 0.9,1: 0.7$, and $1: 0.72$ in $\mathrm{Li}^{+}, \mathrm{Zn}^{2+}$, $\mathrm{Al}^{3+}$, and $\mathrm{Li}^{+} / \mathrm{H}^{+}$configurations, respectively, based on the capacities of individual electrodes in the three-electrode investigations. To validate the different mass balance, the overall voltage of PI-PC full-cells and the individual voltages of the PI anode and PC cathode were monitored during electrochemical experiments in Swagelok ${ }^{\mathrm{TM}}$ T-cells (see Fig. S10 and the ESI for detailed discussion $\dagger$ ). Fig. S10a-c† show that the average cell potential (taken as half the sum of mid-point voltages of charge and discharge branches) increases from 0.58 to 0.74 and further to $0.89 \mathrm{~V}$ when the type of charge carrier changed from $\mathrm{Li}^{+}$to $\mathrm{Zn}^{2+}$, and further to $\mathrm{Al}^{3+}$. This is in good agreement with the CVs of individual electrodes (see Fig. 1b). Accordingly, a higher voltage output of $0.95 \mathrm{~V}$ was exhibited by the full-cell with a mixed $\mathrm{Li}^{+} / \mathrm{H}^{+}$electrolyte (Fig. S10d $\dagger$ ).

Then, the rate capability of full-cells in the aforementioned electrolytes was assessed in a two-electrode configuration by GCD studies at progressively increasing current densities. At a low current density of $0.5 \mathrm{~A} \mathrm{~g}^{-1}$, full-cells were able to deliver $155,145,134$, and $146 \mathrm{~mA} \mathrm{~h} \mathrm{~g}{ }^{-1}$ discharge capacities in $\mathrm{Li}^{+}$, 

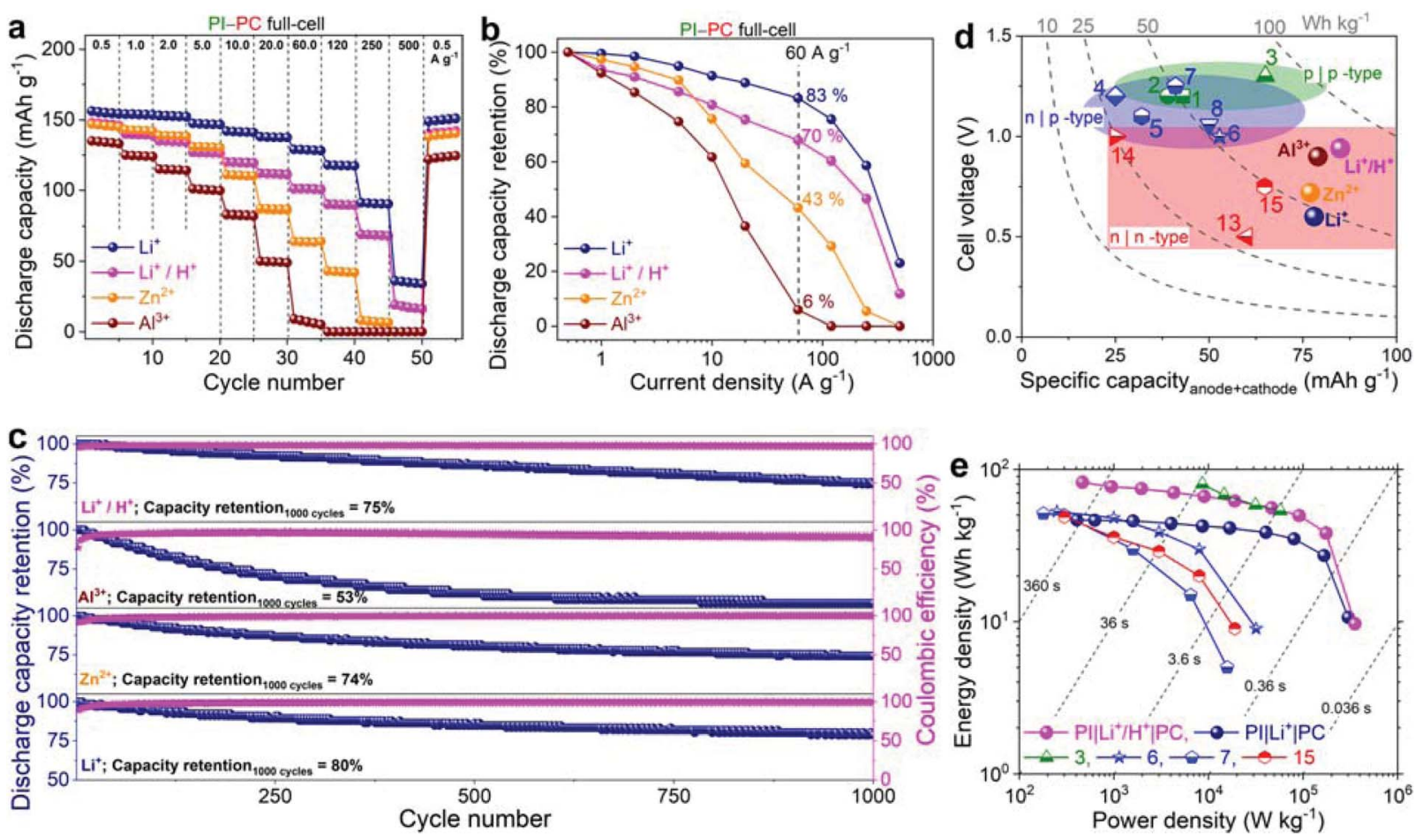

Fig. 5 ( $(a$ and b) Rate performance of PI-PC full-cells: discharge capacity vs. cycle number at different current densities (a), and discharge capacity retention (b). (c) Cyclic performance: discharge capacity retention (\%) and coulombic efficiencies measured at $5 \mathrm{~A} \mathrm{~g}^{-1}$. The capacity and current density in experiments a-c were based on the PI component of the full-cell. (d and e) Comparison of full-cell performance with the state-of-the-art all-polymer aqueous stationary batteries: cell voltage vs. specific capacity (d) and Ragone plot (e). The specific capacity and gravimetric energy/power density were evaluated based on the total mass of the anode and cathode. Both these plots for various all-organic fullcells (mostly, all-polymer) are computed by considering some of the best performing full-cells in their class (see Table S1 $\uparrow$ ). plp-type: half-filled green symbols in the light green region, $\mathrm{n} \mid \mathrm{p}$-type: half-filled blue symbols in the light blue region, $\mathrm{n} \mid \mathrm{n}$-type: half-filled red symbols in the light red region, and filled spheres represent this work.

$\mathrm{Zn}^{2+}, \mathrm{Al}^{3+}$, and $\mathrm{Li}^{+} / \mathrm{H}^{+}$, respectively (Fig. 5a). The rate performance of PI-PC full-cells is once again hampered in the $\mathrm{Li}^{+}<$ $\mathrm{Zn}^{2+}<\mathrm{Al}^{3+}$ order, which is in accordance with the half-cell studies. For instance, when the applied current density was increased to $60 \mathrm{~A} \mathrm{~g}^{-1}$, full-cells achieved discharge capacities of 129,64 , and $7 \mathrm{~mA} \mathrm{~h} \mathrm{~g}^{-1}$, corresponding to 83,43 , and $6 \%$ of their initial capacities in $\mathrm{Li}^{+}, \mathrm{Zn}^{2+}$, and $\mathrm{Al}^{3+}$, respectively (Fig. 5b). Remarkably, full-cells in $\mathrm{Li}^{+}$and $\mathrm{Li}^{+} / \mathrm{H}^{+}$can still deliver discharge capacities of 35 and $17 \mathrm{~mA} \mathrm{~h} \mathrm{~g}^{-1}$, respectively, at even an extremely high current density of $500 \mathrm{~A} \mathrm{~g}^{-1}$ (corresponding to a sub-second charge or discharge), reflecting the unprecedented rate capabilities of both PI and PC in these electrolytes. Furthermore, when the current density was brought back to $0.5 \mathrm{~A} \mathrm{~g}^{-1}$, nearly quantitative capacity recovery was observed in all the cases, discarding irreversible capacity fade during the high current experiments. It is also worth noting here that the average coulombic efficiencies were close to $100 \%$ in $\mathrm{Li}^{+}$and $\mathrm{Zn}^{2+}$ aqueous electrolytes at all the current densities, while slightly lower efficiencies ( $c a$., 94-97\%) were obtained below $1 \mathrm{~A} \mathrm{~g}^{-1}$ with $\mathrm{Al}^{3+}$ and $\mathrm{Li}^{+} / \mathrm{H}^{+}$and then subsequently improved to $>$ 99\% (Fig. S11广).

The cycling stability of PI-PC full-cells was evaluated at a current density of $5 \mathrm{~A} \mathrm{~g}^{-1}$. Full-cells were able to maintain 80 , 74,53 , and $75 \%$ of their initial capacities over 1000 GCD cycles in $\mathrm{Li}^{+}, \mathrm{Zn}^{2+}, \mathrm{Al}^{3+}$, and $\mathrm{Li}^{+} / \mathrm{H}^{+}$, respectively (Fig. $5 \mathrm{c}$ and $\mathrm{S} 12 \dagger$ ). Additionally, the coulombic efficiencies were stabilized at $>99 \%$ after the initial few catechol-to-ortho-quinone activation cycles.

Finally, to demonstrate the availability of our PI-PC full-cells as sustainable high-performance energy storage systems, we compared their performance with that of the state-of-the-art allpolymer aqueous stationary batteries. The maximum attained specific capacities in the range of $78-85 \mathrm{~mA} \mathrm{~h} \mathrm{~g}^{-1}$ were higher than that of the reported AqPBs, and the average cell voltage of $0.95 \mathrm{~V} \mathrm{in} \mathrm{ii}^{+} / \mathrm{H}^{+}$was also notable for the $\mathrm{n} \mid \mathrm{n}$-type configuration (Fig. 5d and Table S1 $\dagger$ ). As shown in the Ragone plot (Fig. 5e), full-cells in $\mathrm{Li}^{+}$and $\mathrm{Li}^{+} / \mathrm{H}^{+}$containing aqueous electrolytes can deliver a maximum energy/power density of $46.5 \mathrm{~W} \mathrm{~h} \mathrm{~kg}^{-1} / 302$ $\mathrm{kW} \mathrm{kg}{ }^{-1}$ and $82.2 \mathrm{~W} \mathrm{~h} \mathrm{~kg}^{-1} / 355 \mathrm{~kW} \mathrm{~kg}^{-1}$, respectively. The concurrent high specific capacity, high cell voltage, and ultrafast kinetics, particularly in the mixed $\mathrm{Li}^{+} / \mathrm{H}^{+}$aqueous electrolyte, endowed the PI-PC full-cell with a steady and high energy density over a wide range of power values that clearly rivals most of the state-of-the-art AqPBs, and also comparable to the pol$y$ (viologen)-poly(2,2,6,6-tetramethylpiperidinyloxy-4-yl acrylamide) aqueous battery (example 3 in Fig. 5 e and Table S1†), ${ }^{28}$ which is based on the plp-type combination. Yet another advantage of $n \mid n$-type combination is that it can make use of lighter weight shuttling cations (e.g., $\mathrm{H}^{+}, \mathrm{Li}^{+}$etc.), in contrast to 
the $\mathrm{p} \mid \mathrm{p}$ - and $\mathrm{n} \mid \mathrm{p}$-type configurations, which require bulky anions and dual ions, respectively, as the electroneutralizing charge carriers. Consequently, when the energy and power density were evaluated based on the total mass of both electrodes and the consumed salt, a small decrease of energy/power density $(<1 \%)$ was noted for PI-PC full-cells in $\mathrm{Li}^{+}$and $\mathrm{Li}^{+} / \mathrm{H}^{+}$, while a substantial lowering of 19,32 , and $30 \%$ energy/power density for the examples $3,{ }^{28} 6,{ }^{30}$ and $7,{ }^{33}$ respectively, is noticeable from their corresponding Ragone plots (Fig. 5e, S13 and Table $\mathrm{S} 1 \dagger)$.

\section{Conclusions}

In this work, we have developed all-organic aqueous batteries comprising a poly(imide) (PI) anode and poly(catechol) (PC) cathode that demonstrated tunable electrochemical performance. We realized this by exploiting the distinctive strength of metal cation-redox core ionic interactions of electrode partners with different charge carriers based on their n-type redox behavior, resulting in various cationic rocking-chair cells. The increase of cell voltage from 0.58 to 0.74 and further to $0.89 \mathrm{~V}$ was achieved, when the type of charge carrier changed from $\mathrm{Li}^{+}$to $\mathrm{Zn}^{2+}$ and to $\mathrm{Al}^{3+}$. Adversely, this gain also comes with the penalty of rate capability and cycling stabilities in the $\mathrm{Li}^{+}<\mathrm{Zn}^{2+}<\mathrm{Al}^{3+}$ order. The PI-PC fullcell also worked in hybrid-ion mode with a mixed $\mathrm{Li}^{+} / \mathrm{H}^{+}$aqueous electrolyte, exhibiting the highest cell voltage of $0.95 \mathrm{~V}$ with good cycling stability and excellent rate capability. The concurrent high specific capacity ( $\left.85 \mathrm{~mA} \mathrm{~h} \mathrm{~g}^{-1}\right)$, high cell voltage $(0.95 \mathrm{~V})$, and ultrafast kinetics (working at $500 \mathrm{~A} \mathrm{~g}^{-1}$, which corresponds to $0.1 \mathrm{~s}$ charge or discharge), particularly in $\mathrm{Li}^{+} / \mathrm{H}^{+}$, provided an impressive energy density of $\sim 80.6 \mathrm{~W} \mathrm{~h} \mathrm{~kg}{ }^{-1}$, where a high value of $\sim 10 \mathrm{~W} \mathrm{~h} \mathrm{~kg}^{-1}$ was still achieved at an unprecedented power density of $\sim 348 \mathrm{~kW} \mathrm{~kg}^{-1}$ based on the total mass of both electrodes and the consumed salt. This overall performance is far superior to that of most of the reported all-polymer aqueous stationary batteries.

Based on the CV, GCD results and DFT calculations, we postulate that PI and PC can be used as universal organic electrodes in numerous Li-ion and post-Li-ion energy storage technologies, including proton and all-polymer batteries, stemming from their versatile n-type charge storage mechanism. The development of such universal organic electrodes is particularly intriguing and gaining popularity among the battery community due to the fact that it demands minimal electrode/device engineering efforts. We hypothesize that the combination of high safety aqueous electrolytes and highperformance PI and PC based organic electrodes could offer a practical option as a truly sustainable energy storage system for wide use in large-scale applications.

\section{Conflicts of interest}

The authors declare no conflict of interest.

\section{Acknowledgements}

RM, NP and AM thank the Spanish Ministry of Science, Innovation and Universities through the SUSBAT project
(Ref. RTI2018-101049-B-I00) (MINECO/FEDER, UE) and the European Research Council (ERC) through the "MFreeB" project (grant agreement No. 726217) for financial support. NP also appreciates Spanish MINECO for the Juan de la Ciervaformation fellowship [FJC2018-037781-I] received to carry out this work. AM acknowledges the TALENTO grant (2017-T1/AMB5264) from the Comunidad de Madrid for financial support. The authors acknowledge the computing facilities of CSUC for providing resources that contributed to the research results reported within this paper. DM and NC are grateful to the financial support of the European Research Council by the Proof of Concept Grant Innovative Polymeric Batteries by 3D Printing (iPes-3DBat) 789875. CD and CJ thank the "Fonds de la Recherche Scientifique” (FRS-FNRS) for funding.

\section{Notes and references}

1 Z. Yang, J. Zhang, M. C. W. Kintner-Meyer, X. Lu, D. Choi, J. P. Lemmon and J. Liu, Chem. Rev., 2011, 111, 3577-3613.

2 S. Chu, Y. Cui and N. Liu, Nat. Mater., 2017, 16, 16-22.

3 M. Li, J. Lu, Z. Chen and K. Amine, Adv. Mater., 2018, 30, 1800561.

4 K. Turcheniuk, D. Bondarev, V. Singhal and G. Yushin, Nature, 2018, 559, 467-470.

5 H. Kim, J. Hong, K.-Y. Park, H. Kim, S.-W. Kim and K. Kang, Chem. Rev., 2014, 114, 11788-11827.

6 J. Huang, Z. Guo, Y. Ma, D. Bin, Y. Wang and Y. Xia, Small Methods, 2019, 3, 1800272.

7 R. Demir-Cakan, M. R. Palacin and L. Croguennec, J. Mater. Chem. A, 2019, 7, 20519-20539.

8 P. Novák, K. Müller, K. S. V. Santhanam and O. Haas, Chem. Rev., 1997, 97, 207-282.

9 S. Muench, A. Wild, C. Friebe, B. Häupler, T. Janoschka and U. S. Schubert, Chem. Rev., 2016, 116, 9438-9484.

10 J. Kim, J. H. Kim and K. Ariga, Joule, 2017, 1, 739-768.

11 S. Lee, G. Kwon, K. Ku, K. Yoon, S.-K. Jung, H.-D. Lim and K. Kang, Adv. Mater., 2018, 30, 1704682.

12 K. Amin, L. Mao and Z. Wei, Macromol. Rapid Commun., 2019, 40, 1800565.

13 J. Xie and Q. Zhang, Small, 2019, 15, 1805061.

14 Y. Y. Lai, X. Li and Y. Zhu, ACS Appl. Polym. Mater., 2020, 2(2), 113-128.

15 N. Casado, D. Mantione, D. Shanmukaraj and D. Mecerreyes, ChemSusChem, 2019, 13(9), 2464-2470.

16 Y. Chen, S. Zhuo, Z. Li and C. Wang, EnergyChem, 2020, 100030.

17 P. Poizot, J. Gaubicher, S. Renault, L. Dubois, Y. Liang and Y. Yao, Chem. Rev., 2020, 120(14), 6490-6557.

18 P. Poizot, F. Dolhem and J. Gaubicher, Curr. Opin. Electrochem., 2018, 9, 70-80.

19 C. Friebe, A. Lex-Balducci and U. S. Schubert, ChemSusChem, 2019, 12, 4093-4115.

20 J. Winsberg, T. Hagemann, T. Janoschka, M. D. Hager and U. S. Schubert, Angew. Chem., Int. Ed., 2017, 56, 686-711.

21 D. P. Tabor, R. Gómez-Bombarelli, L. Tong, R. G. Gordon, M. J. Aziz and A. Aspuru-Guzik, J. Mater. Chem. A, 2019, 7, 12833-12841. 
22 Z. Liu, Y. Huang, Y. Huang, Q. Yang, X. Li, Z. Huang and C. Zhi, Chem. Soc. Rev., 2020, 49, 180-232.

23 D. Chao, W. Zhou, F. Xie, C. Ye, H. Li, M. Jaroniec and S.-Z. Qiao, Sci. Adv., 2020, 6, eaba4098.

24 R. Emanuelsson, M. Sterby, M. Strømme and M. Sjödin, J. Am. Chem. Soc., 2017, 139, 4828-4834.

25 G. Hernández, N. Casado, A. M. Zamarayeva, J. K. Duey, M. Armand, A. C. Arias and D. Mecerreyes, ACS Appl. Energy Mater., 2018, 1, 7199-7205.

26 Y. Zhang, Y. An, L. Wu, H. Chen, Z. Li, H. Dou, V. Murugadoss, J. Fan, X. Zhang, X. Mai and Z. Guo, J. Mater. Chem. A, 2019, 7, 19668-19675.

27 N. Chikushi, H. Yamada, K. Oyaizu and H. Nishide, Sci. China, Ser. B: Chem., 2012, 55, 822-829.

28 N. Sano, W. Tomita, S. Hara, C.-M. Min, J.-S. Lee, K. Oyaizu and H. Nishide, ACS Appl. Mater. Interfaces, 2013, 5, 13551361.

29 K. Sato, R. Katagiri, N. Chikushi, S. Lee, K. Oyaizu, J.-S. Lee and H. Nishide, Chem. Lett., 2017, 46, 693-694.

30 X. Dong, H. Yu, Y. Ma, J. L. Bao, D. G. Truhlar, Y. Wang and Y. Xia, Chem. - Eur. J., 2017, 23, 2560-2565.

31 H. Long, W. Zeng, H. Wang, M. Qian, Y. Liang and Z. Wang, Adv. Sci., 2018, 5, 1700634.

32 K. Hatakeyama-Sato, H. Wakamatsu, K. Yamagishi, T. Fujie, S. Takeoka, K. Oyaizu and H. Nishide, Small, 2019, 15, 1805296.

33 Y. Zhang, Y. An, B. Yin, J. Jiang, S. Dong, H. Dou and X. Zhang, J. Mater. Chem. A, 2019, 7, 11314-11320.

34 H. Qin, Z. P. Song, H. Zhan and Y. H. Zhou, J. Power Sources, 2014, 249, 367-372.

35 S. Gheytani, Y. Liang, F. Wu, Y. Jing, H. Dong, K. K. Rao, X. Chi, F. Fang and Y. Yao, Adv. Sci., 2017, 4, 1700465.

36 X. Fan, F. Wang, X. Ji, R. Wang, T. Gao, S. Hou, J. Chen, T. Deng, X. Li, L. Chen, C. Luo, L. Wang and C. Wang, Angew. Chem., Int. Ed., 2018, 57, 7146-7150.

37 J. Bitenc, K. Pirnat, T. Bančič, M. Gaberšček, B. Genorio, A. Randon-Vitanova and R. Dominko, ChemSusChem, 2015, 8, 4128-4132.

38 Y. Liang, Y. Jing, S. Gheytani, K.-Y. Lee, P. Liu, A. Facchetti and Y. Yao, Nat. Mater., 2017, 16, 841-848.

39 T. Liu, K. C. Kim, B. Lee, Z. Chen, S. Noda, S. S. Jang and S. W. Lee, Energy Environ. Sci., 2017, 10, 205-215.

40 S. Zhang, W. Zhao, H. Li and Q. Xu, ChemSusChem, 2020, 13, 188-195.

41 N. Patil, A. Mavrandonakis, C. Jérôme, C. Detrembleur, J. Palma and R. Marcilla, ACS Appl. Energy Mater., 2019, 2, 3035-3041.

42 N. Patil, A. Aqil, F. Ouhib, S. Admassie, O. Inganäs, C. Jérôme and C. Detrembleur, Adv. Mater., 2017, 29, 1703373.

43 G. Hernández, N. Casado, R. Coste, D. Shanmukaraj, L. Rubatat, M. Armand and D. Mecerreyes, RSC Adv., 2015, 5, 17096-17103.
44 L. J. Krause, J. Electrochem. Soc., 1988, 135, 1137.

45 L. J. Krause, J. Electrochem. Soc., 1989, 136, 1379.

46 W. Deng, Y. Shen, J. Qian and H. Yang, Chem. Commun., 2015, 51, 5097-5099.

47 L. Yan, C. Zhao, Y. Sha, Z. Li, T. Liu, M. Ling, S. Zhou and C. Liang, Nano Energy, 2020, 73, 104766.

48 H. Wang, R. Emanuelsson, A. Banerjee, R. Ahuja, M. Strømme and M. Sjödin, J. Phys. Chem. C, 2020, 124, 13609-13617.

49 P. S. Guin, S. Das and P. C. Mandal, Int. J. Electrochem., 2011, 2011, 1-22.

50 M. Svensson, Conducting polymers for battery applications, Uppsala universitet, 2020.

51 Y. J. Kim, W. Wu, S.-E. Chun, J. F. Whitacre and C. J. Bettinger, Adv. Mater., 2014, 26, 6572-6579.

52 N. Patil, C. Jérôme and C. Detrembleur, Prog. Polym. Sci., 2018, 82, 34-91.

53 M. Krogsgaard, V. Nue and H. Birkedal, Chem. - Eur. J., 2016, 22, 844-857.

54 Y. Geng, S.-X. Wu, H. Li, X. Tang, Y. Wu, Z.-M. Su and Y. Liao, J. Mater. Chem., 2011, 21, 15558.

55 G. S. Vadehra, R. P. Maloney, M. A. Garcia-Garibay and B. Dunn, Chem. Mater., 2014, 26, 7151-7157.

56 T. Yokoji, H. Matsubara and M. Satoh, J. Mater. Chem. A, 2014, 2, 19347-19354.

57 N. Patil, M. Aqil, A. Aqil, F. Ouhib, R. Marcilla, A. Minoia, R. Lazzaroni, C. Jérôme and C. Detrembleur, Chem. Mater., 2018, 30, 5831-5835.

58 K. H. Jung, G. S. Jeong, C. Y. Go and K. C. Kim, Energy Storage Mater., 2020, 24, 237-246.

59 G. Dai, Y. Gao, Z. Niu, P. He, X. Zhang, Y. Zhao and H. Zhou, ChemSusChem, 2020, 13(9), 2264-2270.

60 A. Jouhara, N. Dupré, A.-C. Gaillot, D. Guyomard, F. Dolhem and P. Poizot, Nat. Commun., 2018, 9, 4401.

61 Q. Lin, Q. Li, C. Batchelor-McAuley and R. G. Compton, J. Phys. Chem. C, 2015, 119, 1489-1495.

62 N. Patil, D. Cordella, A. Aqil, A. Debuigne, S. Admassie, C. Jérôme and C. Detrembleur, Macromolecules, 2016, 49, 7676-7691.

63 K. Pirnat, N. Casado, L. Porcarelli, N. Ballard and D. Mecerreyes, Macromolecules, 2019, 52, 8155-8166.

64 M. Sterby, R. Emanuelsson, X. Huang, A. Gogoll, M. Strømme and M. Sjödin, Electrochim. Acta, 2017, 235, 356-364.

65 V. Augustyn, J. Come, M. A. Lowe, J. W. Kim, P.-L. Taberna, S. H. Tolbert, H. D. Abruña, P. Simon and B. Dunn, Nat. Mater., 2013, 12, 518-522.

66 Y. Gogotsi and R. M. Penner, ACS Nano, 2018, 12, 2081-2083. 67 Y. Jiang and J. Liu, Energy Environ. Mater., 2019, 2, 30-37.

68 Y. Wang, X. Cui, Y. Zhang, L. Zhang, X. Gong and G. Zheng, Adv. Mater., 2016, 28, 7626-7632. 